\title{
Serum protein profiles and C-reactive protein in natural canine filariasis
}

\author{
Sariya Asawakarn ${ }^{1}$ (D) Sujin Sirisawadi ${ }^{1}$ (D), Nanthida Kunnasut ${ }^{1}$ (D) Patchana Kamkong ${ }^{2}$ (iD) and \\ Piyanan Taweethavonsawat ${ }^{2}$ (i)
}

1. Biochemistry Unit, Department of Veterinary Physiology, Faculty of Veterinary Science, Chulalongkorn University, Bangkok, 10330, Thailand; 2. Parasitology Unit, Department of Veterinary Pathology, Faculty of Veterinary Science, Chulalongkorn University, Bangkok, 10330, Thailand.

Corresponding author: Piyanan Taweethavonsawat, e-mail: piyanan.t@chula.ac.th, Co-authors: SA: sariya.a@chula.ac.th, SS: ssirisawadi@yahoo.com, NK: pui_unn@hotmail.com, PK: miint.pat@gmail.com

Received: 07-12-2020, Accepted: 24-02-2021, Published online: 10-04-2021

doi: www.doi.org/10.14202/vetworld.2021.860-864 How to cite this article: Asawakarn S, Sirisawadi S, Kunnasut N, Kamkong P, Taweethavonsawat P (2021) Serum protein profiles and C-reactive protein in natural canine filariasis, Veterinary World, 14(4): 860-864.

\begin{abstract}
Background and Aim: Canine filariasis is caused by several species of filarial worms. The pathophysiological response to infection is mainly due to the filaria lifecycle. Laboratory detection methods to assess the pathological alterations characteristic of filariasis are needed urgently. Serum protein profiles and C-reactive protein (CRP) levels are used widely to diagnose several animal diseases. This study aimed to determine the serum protein profiles and CRP levels in dogs infected with Dirofilaria immitis or Brugia pahangi or both parasites.
\end{abstract}

Materials and Methods: Blood samples were collected from 980 dogs presenting at animal hospitals and veterinary clinics in Bangkok and its vicinity. The presence of microfilaria in samples was determined using a buffy coat smear and staining with Wright-Giemsa. The sheathed and unsheathed microfilaria species were identified by acid phosphatase staining. Forty positive samples were tested. The serum protein profiles were identified by agarose gel electrophoresis. The CRP concentration was measured using a fluorescent immunoassay.

Results: Albumin levels and albumin-to-globulin ratios were significantly lower, and total protein, $\beta 2$ globulin, and $\gamma$ globulin levels were significantly elevated in dogs infected with $D$. immitis and B. pahangi compared with reference values in normal dogs. The average CRP concentrations in dogs infected with D. immitis or B. pahangi were 69.9 and $12.9 \mathrm{mg} / \mathrm{L}$, respectively.

Conclusion: The total protein and $\gamma$ globulin levels increased in canine filariasis compared with the normal reference range. The CRP concentration in dogs infected with $D$. immitis was extremely high, whereas that in dog infected with $B$. pahangi was normal.

Keywords: Brugia pahangi, C-reactive protein, Dirofilaria immitis, dogs, serum protein.

\section{Introduction}

Canine filariasis is a prominent mosquito-borne disease that occurs worldwide, including in Thailand. Filariasis is a considerable public health concern in tropical and subtropical areas. Several species of filarial worms, including Dirofilaria immitis, Dirofilaria repens, Brugia pahangi, and Acanthocheilonema reconditum, can cause filariasis. These species have been reported in Thailand [1]. D. immitis infection, which causes canine heartworm disease, is the most pathogenic filarial parasite. The clinical signs of filariasis are exercise intolerance, coughing, ascites, and heart failure. The pathophysiological response to heartworm infection is mainly due to the living adult worms in the pulmonary arteries and right ventricle. In addition, dead microfilaria and released adult worms

Copyright: Asawakarn, et al. Open Access. This article is distributed under the terms of the Creative Commons Attribution 4.0 International License (http://creativecommons.org/licenses/ by/4.0/), which permits unrestricted use, distribution, and reproduction in any medium, provided you give appropriate credit to the original author(s) and the source, provide a link to the Creative Commons license, and indicate if changes were made. The Creative Commons Public Domain Dedication waiver (http:// creativecommons.org/publicdomain/zero/1.0/) applies to the data made available in this article, unless otherwise stated. can release an endosymbiotic bacterium, named Wolbachia pipientis. This bacterium is crucial to the pathophysiological response to canine heartworm disease. The severity of infection is characterized by endocarditis, with intimal proliferation and thickened vessel walls [2,3]. Brugia spp. cause lymphatic filariasis; in humans, these pathogens, especially Brugia malayi, cause elephantiasis. In pets, B. pahangi is transmitted by mosquitoes and its lifecycle is similar to that of other filarial worms. Infective larvae enter peripheral lymphatics, migrate to the nearest lymph node, and develop for 2 weeks before migrating to other lymphatics, where the larvae mature and produce lymphadenitis, granulomatous lymphangitis, and lymphangiectasia. Notably, in dogs, B. pahangi does not cause elephantiasis as it does in humans. Infected dogs are generally asymptomatic, although lymphadenopathy and lymphedema have been reported in some cases $[4,5]$.

The development of laboratory methods to assess the pathological alterations characteristic of the disease is needed urgently. In addition, new tools are needed to determine the health status of dogs infected with $D$. immitis or $B$. pahangi, including tools for 
disease staging and accurate prognoses. Serum protein profiles and inflammatory biomarkers are suitable tools to monitor infected animals. Serum protein profiles are useful for veterinarians to monitor the health status of animals. Major canine serum proteins are separated into five or six bands, including albumin, $\alpha 1$ globulin, $\alpha 2$ globulin, $\beta$ globulin, and $\gamma$ globulin. The $\beta$ globulin fraction can separate into the $\beta 1$ globulin and $\beta 2$ globulin fractions. Serum protein profiles have been used widely as a diagnostic tool to monitor the status of infectious and other diseases, such as multiple myeloma in dogs [6-10].

The acute-phase response is an early defense of the body in response to trauma, inflammation, or infection. The acute-phase response is part of the innate host defense system and systemic effects, including fever, leukocytosis, and increased blood cortisol. C-reactive protein (CRP) is one of the acutephase proteins. CRP was first described as an acutephase protein in 1930 and named for its ability to bind to C-polysaccharide from Pneumococcus pneumonia [11,12]. Pro-inflammatory cytokines, such as interleukin 6 (IL-6) and tumor necrosis factor-alpha (TNF- $\alpha$ ), stimulate the liver to produce CRP and release it into the bloodstream. CRP is a major acutephase protein in dogs; however, information on serum protein profiles and CRP levels in dogs infected with D. immitis (i.e., canine heartworm disease) or B. pahangi is limited.

The aim of this study was to determine and to compare the serum protein profiles and CRP level in dogs infected with $D$. immitis or $B$. pahangi with normal reference values from healthy dogs, with the goal of utilizing these parameters to monitor disease status.

\section{Materials and Methods}

\section{Ethical approval}

The research protocol was approved by Chulalongkorn University Animal Committee (approval no. 1931052).

\section{Study period and location}

Samples were collected from private Small Animal Hospitals and Veterinary Clinic in Bangkok from August 2019 to July 2020.

\section{Sample collection}

Blood samples were collected from 980 canines (Canis familiaris). Some dogs exhibited the clinical signs of filariasis, including exercise intolerance, coughing, and ascites. However, most dogs did not exhibit any clinical signs of filariasis. All samples were tested to determine the presence of microfilaria using buffy coat blood smears and staining with Wright-Giemsa. Sheathed and unsheathed microfilaria were identified to determine the filarial species using acid phosphatase staining [1]. The number of dogs positive for $D$. immitis or $B$. pahangi or both parasites was 24,15 , and 1 , respectively. All canine blood samples were collected in serum collection tubes. All serum samples were kept at $-20^{\circ} \mathrm{C}$ until analyses.

\section{Determination of the serum protein profile by electrophoresis}

Total protein concentrations in the 40 positive serum samples were determined using a photometric colorimetric test or a biuret method test kit (Human ${ }^{\circledR}$, Wiesbaden, Germany). Proteins were separated by agarose gel electrophoresis $\left(\mathrm{SPIFE}^{\circledR}\right.$ Split Beta SPE kit, Helena Laboratories, Beaumont, Texas, USA) to examine the serum protein profiles. 1.3 milligram protein of each serum sample were electrophoresed at $400 \mathrm{~V}$ for $6 \mathrm{~min}$. The gels were pre-dried at $53^{\circ} \mathrm{C}$ for $12 \mathrm{~min}$, stained with acid blue staining solution, and destained with citric acid using an automated machine $\left(\right.$ Spife $^{\circledR} 3000$, Helena Laboratories). The density of protein bands was analyzed using the Quickscan Touch program (Helena Laboratories). The specimen electrophoresis protein serum (SPEP) data from dogs infected with $D$. immitis or B. pahangi were compared to the reference ranges of normal, uninfected dogs reported by Kaneko [13].

\section{Measurement of CRP concentration}

The CRP concentrations were measured using a fluorescent immunoassay (Vcheck Canine CRP 2.0 Test Kit, Bionote, Gyeonggi-do, South Korea). The CRP concentrations were determined in serum samples from dogs infected with $D$. immitis $(\mathrm{n}=6)$ or B. pahangi $(\mathrm{n}=6)$ or both parasites $(\mathrm{n}=1)$. Five microliters of each sample were diluted with the diluent buffer (to $100 \mu \mathrm{L}$ ), mixed, and added to the test device (V200 Analyzer, Bionote, South Korea). A CRP concentration of more than $30 \mathrm{mg} / \mathrm{L}$ represented an abnormal value.

\section{Statistical analysis}

SPEP data from infected dogs were analyzed using a general linear model (GLM) with the online SAS version 9.4 (SAS Inst. Inc., Cary, NC, USA) or SAS University Edition (https://www.sas.com/ en_us/software/university-edition.html). The GLM was $y=t r t+$ method + trt $*$ method $+\mathrm{e}$, where $y$ was the serum protein value from each filarial worm species and method of use, trt is a factor from each filarial worm species, method is a factor from the laboratory technique used to measure serum protein profiles, $t r t^{*}$ method is the interaction term between the two factors, and $e$ is the residual value from each observation.

\section{Results}

Dogs infected with D. immitis and B. pahangi showed significantly lower albumin levels and albumin-to-globulin $(\mathrm{A} / \mathrm{G})$ ratios and significantly elevated total protein, $\beta 2$ globulin, and $\gamma$ globulin levels compared with reference values of normal dogs (Table-1). The serum protein electropherograms are shown in Figures-1-4. The serum protein electrophoretogram for dogs infected with both is shown in Figure-5. 
Table-1: The total protein, albumin, a1 globulin, a2 globulin, $\beta 1$ globulin, $\beta 2$ globulin, and $y$ globulin levels and albumin-globulin $(A / G)$ ratio.

\begin{tabular}{lccc}
\hline $\begin{array}{l}\text { Variable } \\
\text { (g/dL) }\end{array}$ & $\begin{array}{c}\text { Dirofilaria } \\
\text { immitis positive } \\
\text { (mean=SD) } \\
(\mathbf{n = 2 4 )}\end{array}$ & $\begin{array}{c}\text { Brugia pahangi } \\
\text { positive } \\
(\mathbf{m} \text { Rean } \pm \text { SD })\end{array}$ & $\begin{array}{c}\text { Reference } \\
\text { range [13] }\end{array}$ \\
\hline Total & $9.22 \pm 2.40$ & $8.50 \pm 1.75$ & $5.40-7.10$ \\
protein & & & \\
Albumin & $2.07 \pm 0.70$ & $2.28 \pm 0.50$ & $2.60-3.30$ \\
Alpha-1 & $0.34 \pm 0.17$ & $0.43 \pm 0.18$ & $0.20-0.50$ \\
Alpha-2 & $0.66 \pm 0.55$ & $0.52 \pm 0.45$ & $0.30-1.10$ \\
Beta-1 & $1.15 \pm 0.53$ & $0.87 \pm 0.46$ & $0.70-1.30$ \\
Beta-2 & $2.23 \pm 1.02$ & $1.79 \pm 0.06$ & $0.60-1.40$ \\
Gamma & $2.77 \pm 1.84$ & $2.63 \pm 1.17$ & $0.90-2.20$ \\
A/G ratio & $0.33 \pm 0.12$ & $0.41 \pm 0.15$ & $0.59-1.11$ \\
\hline
\end{tabular}

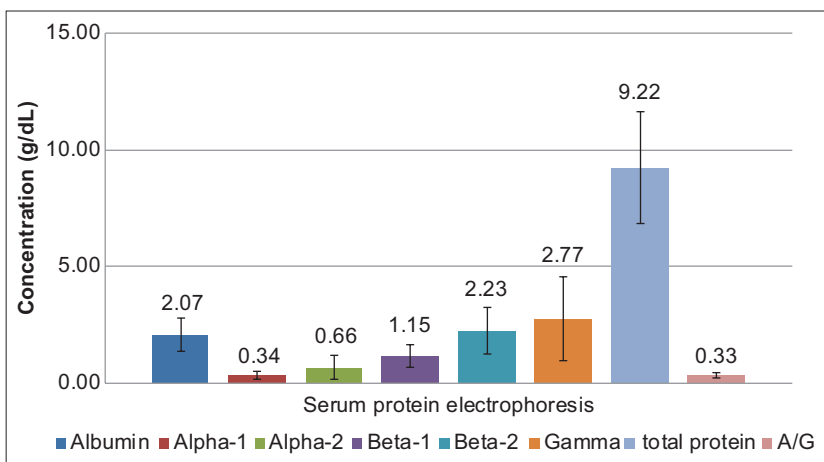

Figure-1: The albumin, $\alpha 1$ globulin, $\alpha 2$ globulin, $\beta 1$ globulin, $\beta 2$ globulin, $\gamma$ globulin, and total protein concentrations (mean \pm standard deviation in $\mathrm{g} / \mathrm{dL}$ ) and albumin-globulin $(\mathrm{A} / \mathrm{G})$ ratio of dogs infected with Dirofilaria immitis. The numbers indicate the average values.

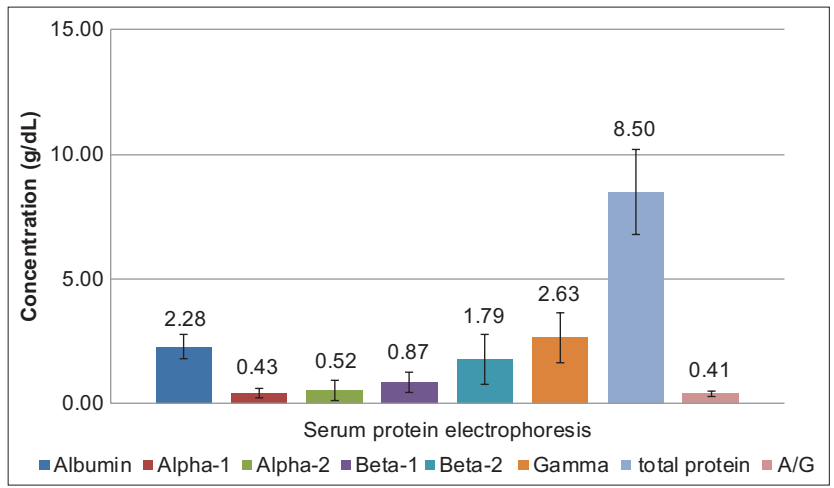

Figure-2: The albumin, $\alpha 1$ globulin, $\alpha 2$ globulin, $\beta 1$ globulin, $\beta 2$ globulin, $\gamma$ globulin, and total protein concentrations (mean \pm standard deviation in $\mathrm{g} / \mathrm{dL}$ ) and albumin-globulin $(\mathrm{A} / \mathrm{G})$ ratio of dogs infected with Brugia pahangi. The numbers indicate the average values.

The CRP concentrations of dogs infected with only D. immitis $(\mathrm{n}=6)$ were between 13.6 and $116.9 \mathrm{mg} / \mathrm{L}$, with an average of $69.6 \mathrm{mg} / \mathrm{L}$. In addition, dogs had high CRP concentration; they may have to monitor health status during the treatment process. There were four samples with CRP concentrations above $30 \mathrm{mg} / \mathrm{L}$ and two samples below $30 \mathrm{mg} / \mathrm{L}$. The CRP concentrations of dogs infected with $B$. pahangi $(\mathrm{n}=6)$ were in the normal range $(<30 \mathrm{mg} / \mathrm{L}):<10 \mathrm{mg} / \mathrm{L}(\mathrm{n}=4)$, $18.8 \mathrm{mg} / \mathrm{L}(\mathrm{n}=1)$, and $31 \mathrm{mg} / \mathrm{L}(\mathrm{n}=1)$. The average CRP

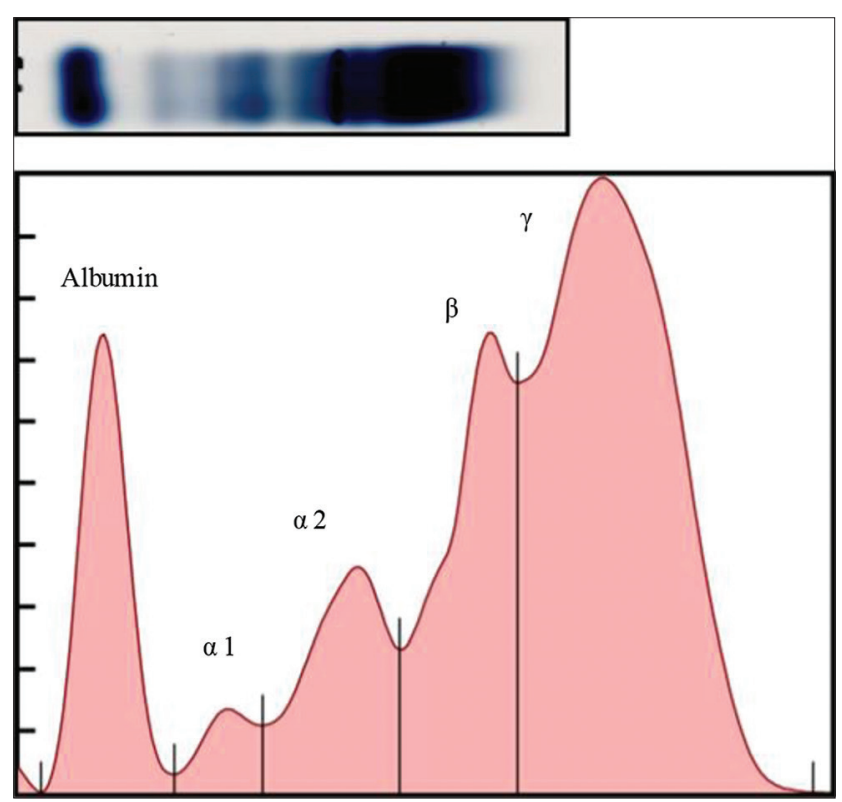

Figure-3: A representative electrophoretogram (top) of an infected with Dirofilaria immitis. The serum protein profile (bottom) shows the reduced albumin peak, increased $\beta$ globulin, and $\gamma$ globulin peaks (hyperglobulinemia).
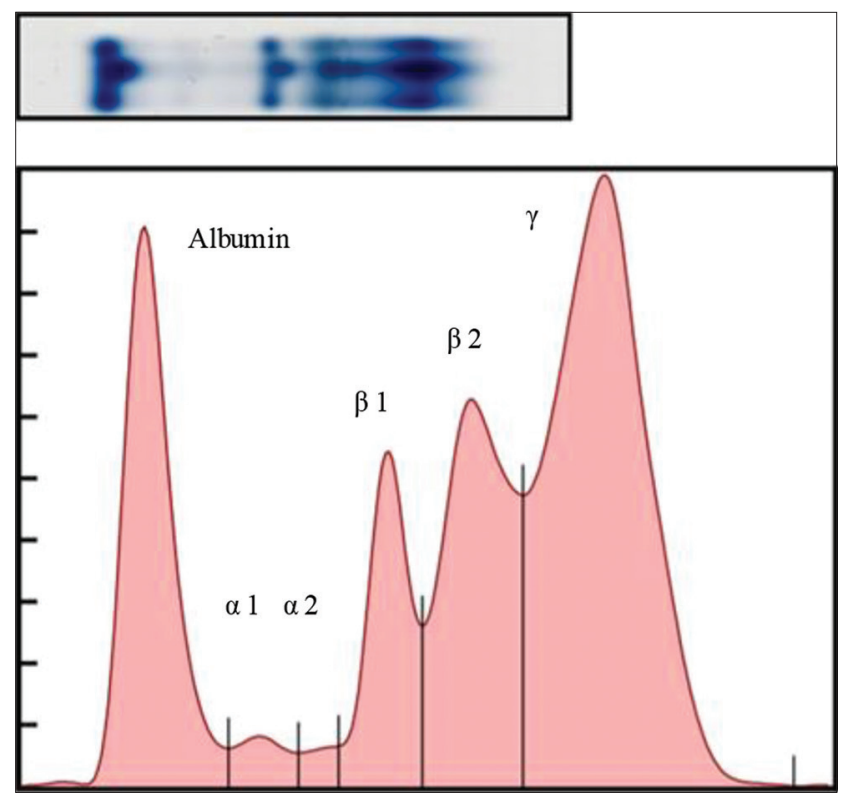

Figure-4: A representative electrophoretogram (top) of a dog infected with Brugia pahangi. The serum protein profile (bottom) shows the elevated $\beta$ globulin and $\gamma$ globulin peaks.

concentration was $12.9 \mathrm{mg} / \mathrm{L}$ in dogs infected with B. pahangi. The CRP concentration in the dog infected with both $D$. immitis and B. pahangi was $>200 \mathrm{mg} / \mathrm{L}$.

\section{Discussion}

Determining the serum protein profile is a basic test used in animal hematology and clinical chemistry to monitor the patient's health and disease status. Variations in serum protein profiles commonly occur as secondary symptoms in numerous diseases and may be the primary symptom of certain conditions. Several factors may influence the concentration of serum proteins. Serum protein profiles are an excellent method 


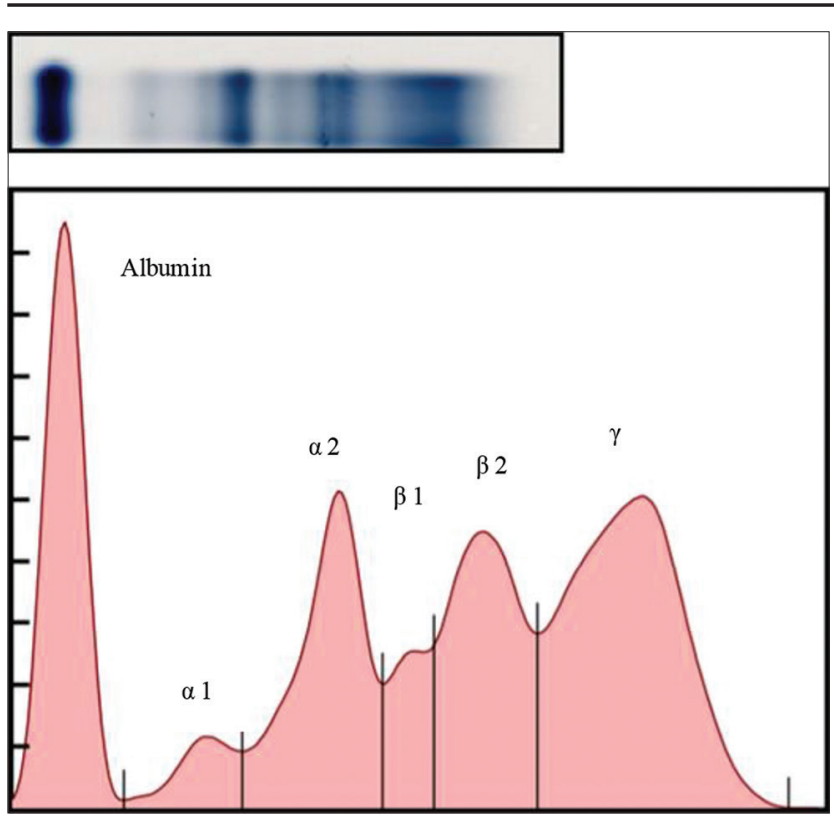

Figure-5: A representative electrophoretogram (top) of a dog infected with Dirofilaria immitis and Brugia pahangi.

to detect acute or chronic inflammation and stimulate humoral immune response [6,14].

The Spilt Beta SPE Kit separates serum proteins into five or six bands: Albumin, $\alpha 1$ globulin, $\alpha 2$ globulin, $\beta$ globulin, and $\gamma$ globulin. The $\beta$ globulin peak can also be split into $\beta 1$ and $\beta 2$ globulin peaks. Each globulin fraction consists of acute-phase proteins or antibodies, and sometimes both [15]. In dogs infected with $D$. immitis or $B$. pahangi, albumin levels and the $\mathrm{A} / \mathrm{G}$ ratio were reduced compared with normal reference dog values [13]. Reduced albumin levels are usually caused by starvation, liver insufficiency, kidney disease, congestive heart failure, or parasitic disease $[6,8,10]$. Canine filariasis leads to marked changes in the parameters used to evaluate liver and kidney functions [16]. A reduced $\mathrm{A} / \mathrm{G}$ ratio is caused by the overproduction of globulins. In this study, total protein and $\gamma$ globulin levels were elevated in dogs infected with $D$. immitis or $B$. pahangi compared with the levels in healthy dogs [13]. The high level of total proteins is indicative of hyperglobulinemia because of the humoral response induced by $D$. immitis. The high level of $\gamma$ globulin indicates the high production of immunoglobulins (Igs), such as $\mathrm{IgG}$, in response to chronic inflammation. Hyperglobulinemia can be caused by chronic infection, inflammation, neoplasia, and parasitic diseases, such as dirofilariasis, scabies, and Ehrlichia infection [17]. Clinical signs of heartworm disease appear as chronic infection and marked allergic response to the adult worms and microfilariae. Hyperglobulinemia is an expected feature of canine heartworm disease and can be either polyclonal or monoclonal gammopathy. We noted clonal gammopathy using the SPE kit, which identified the monoclonal protein IgG. Dirofilariasis has been hypothesized to elicit the atypical benign clonal proliferation of plasma cells [18]. In dogs, $\gamma$ globulin fractions are composed of various classes of Igs, and CRP also migrates in this fraction $[19,20]$. Moreover, the elevated $\gamma$ globulin level in dogs infected with only $D$. immitis might be related to the high CRP concentration. Similar to dogs infected with $D$. immitis, dogs infected with only $B$. pahangi showed a reduced albumin level and $\mathrm{A} / \mathrm{G}$ ratio, and elevated total protein, $\beta 2$ globulin, and $\gamma$ globulin levels compared with reference levels in healthy dogs [13]. In humans infected with Loa loa, total serum protein $\beta$ globulin and $\gamma$ globulin fractions with monoclonal gammopathy are elevated. The albumin, $\mathrm{A} / \mathrm{G}$ ratio, and $\alpha$-globulin were all normal in dogs with B. pahangi [21].

CRP is a major canine acute-phase protein that increases rapidly in a wide range of inflammatory conditions; CRP is especially high in chronic conditions. From our results, the average CRP concentration in dogs infected with only $D$. immitis was higher than the reference range, but the CRP concentration was normal in dogs infected with only B. pahangi. The CRP concentration in dogs infected with both $D$. immitis and B. pahangi was markedly elevated (>200 mg/L). A striking increase in CRP and decrease in albumin and paraoxonase- 1 activity have been observed in canine heartworm disease [22]. CRP levels are elevated in canine heartworm disease because of inflammation involved in the pathogenesis [23]. Heartworm disease leads to pulmonary hypertension and, in the late stage, may induce right-side cardiac insufficiency. Adult worms are localized in the pulmonary arteries, which induces endothelial damage or proliferative endocarditis. The CRP concentration can be used as a marker of endothelial arteritis and pulmonary hypertension in dogs infected with D. immitis [24]. However, the CRP concentration in dogs infected with $B$. pahangi was in the normal range; those dogs were mostly asymptomatic. In humans, the CRP concentration in patients with asymptomatic microfilaremia was lower than in patients with chronic lymphatic pathology. The patients with chronic lymphatic obstruction caused by the filarial parasite Wuchereria bancrofti had elevated serum CRP [25]. The extremely high CRP concentration in the coinfected dogs indicates that the inflammatory response may be caused by $D$. immitis infection.

\section{Conclusion}

The serum protein profiles and CRP concentrations in canine filariasis can reflect the health status of infected dogs. The total protein and $\gamma$ globulin levels increased in canine filariasis compared with the normal reference range. The CRP concentrations in dogs infected with $D$. immitis were extremely high, whereas those in dogs infected with $B$. pahangi were normal. This information can be utilized by veterinarians to monitor infected dogs during treatment.

\section{Authors' Contributions}

SA and PT designed the experiments. NK, SS, and $\mathrm{PK}$ contributed to the analysis and interpretation 
of data. SA and PT wrote the manuscript. NK, SS, and PK assisted in writing and revision of the manuscript. All authors have read and approved the final manuscript.

\section{Acknowledgments}

The authors would like to thank Assist. Prof. Chatree Khatiworavage for statistical analysis. This study was supported by grants from Ratchadapisek, Chulalongkorn University, Thailand (Grant no. CU_ GR_63_42_31_03).

\section{Competing Interests} interests.

The authors declare that they have no competing

\section{Publisher's Note}

Veterinary World remains neutral with regard to jurisdictional claims in published institutional affiliation.

\section{References}

1. Chungpivat, S. and Taweethavornsawat, P. (2008) The differentiation of microfilariae in dogs and cats using Giemsa's staining and the detection of acid phosphatase activity. J. Thai. Vet. Pract., 20(1): 47-55.

2. Kramer, L., Grandi, G., Leoni, M., Passeri, B., McCall, J., Genchi, C., Montarino, M. and Bazzocchi, C. (2008) Wolbachia and its influence on the pathology and immunology of Dirofilaria immitis infection. Vet. Parasitol., 158(3): 191-195.

3. McCall, J.W., Genchi, C., Kramer, L.H., Gurrero, J. and Venco, L. (2008) Heartworm disease in animals and humans. Adv. Parasitol., 66:193-285.

4. Kaikuntod, M., Thongkorn, K., Tiwananthagorn, S. and Boonyapakorn, C. (2018) Filarial worms in dogs in Southeast Asia. Vet. Integr. Sci., 16(2): 1-17.

5. Kobasa, T., Thammapalo, S., Suvannalabha, S., Armesombun, A., Loymak, S., Sawat, L. and Choochite, W. (2004) Identification of Brugia malayi like microfilaria in naturally infected cats from Narathiwat province, South Thailand. J. Trop. Med. Parasitol., 27(1): 21-25.

6. Jania, B. and Andraszek, K. (2016) Application of native agarose gel electrophoresis of serum proteins in veterinary diagnostics. J. Vet. Res., 60(4): 501-508.

7. McGrotty, Y. and Knottenbelt, C. (2002) Significance of plasma protein abnormalities in dogs and cats. Practice, 24(9): 512-517.

8. O'Connell, T.X., Horita, T.J. and Kasravi, B. (2005) Understanding and interpreting serum protein electrophoresis. Am. Fam. Physician, 71(1): 105-112.

9. Thotova, C., Nagy, O. and Kovac, G. (2016) Serum proteins and their diagnostic utility in veterinary medicine: A review. Vet. Med., 61(9): 475-496.

10. Vavricka, S.R., Burri, E., Beglinger, C. and Degen, L.
(2009) Serum protein electrophoresis: An underused but very useful test. Digestion, 79(4): 203-210.

11. Carreton, E., Morchon, R. and Montaya-Alonso, J.A. (2017) Cardiopulmonary and inflammatory biomarkers in heartworm disease. Parasit. Vectors, 10(2): 534.

12. Sproston, N.R. and Ashworth, J.J. (2018) Role of C-reactive protein at sites of inflammation and infection. Front. Immunol., 9:754

13. Kaneko, J.J. (1997) Serum proteins and the dysproteinemias. In: Kaneko, J.J., editor. Clinical Biochemistry of Domestic Animals. $5^{\text {th }}$ ed. Academic Press, San Diego, CA. p117-138.

14. Histrova, J. and Genova, M. (2015) Serum protein electrophoresis by agarose gel M spike screening and beyond-review. Int. J. Sci. Res., 6(6): 1463-1466.

15. Moore, A.R. and Avery, P.R. (2019) Protein characterization using electrophoresis and immunofixation; a case-based review of dogs and cats. Vet. Clin. Pathol., 48(1): 29-44.

16. Heshem, M. and Badawy, A. (2007) Hematological and biochemical studies on filariasis of dogs. Internet J. Vet. Med., 4(2): $1-7$

17. Capraiis, D., Sassanelli, M., Paradies, P., Otranto, D. and Lia, R. (2009) Monoclonal gammopathy associated with heartworm disease in a dog. J. Am. Anim. Hosp. Assoc., 45(6): 295-300.

18. Wahed, A. and Dasgupta, A. (2015) Monoclonal gammopathy and its detection. In: Hematology and Coagulation: A Comprehensive Review for Board Preparation, Certification and Clinical Practice. Elsevier, Amsterdam. p117-123.

19. Jarensky, A.K., Bondzio, A., Murugaiyan, J., Siebert, U., Roesler, U., Kohn, B. and Einspanier, R. (2014) Characterization of native C-reactive protein (CRP) and the corresponding liver mRNA in dogs. Biochem. Biophys. Res. Commun., 452(3): 462-467.

20. Yamamoto, S. (1992) Isolation of canine C-reactive protein and characterization of its properties. Vet. Immunol. Immunopathol., 30(4): 329-339.

21. Laskar, D.B., Rose, M., Gupta, R., Tanowitz, HB. and Haseeb, MA. (2018) Case report: Monoclonal gammopathy of undetermined significance is associated with Loa loa infection. Am. J. Trop. Med. Hyg., 99(5): 1206-1210.

22. Mendez, J.C., Carreton, E., Martinez, S., Tvarijonaviciute,A., Ceron, J.J. and Montoya-Alonso, JA. (2015) Acute phase response in heartworm infected dogs after adulticide treatment. Vet. Parasitol., 209(3-4): 197-201.

23. Yoon, W.K., Kim, Y.W., Suh, S., Choi, R., Lee, S.G. and Hyun, C. (2017) Evaluation of cardiopulmonary and inflammatory markers in dogs with heartworm infection during treatment with the 2014 American Heartworm society recommended treatment protocol. Parasit. Vectors, 10(2): 535.

24. Venco, L., Bertazzolo, W., Giordano, G. and Paltrinieri, S. (2014) Evaluation of C-reactive protein as a clinical biomarker in naturally heartworm-infected dogs: A field study. Vet. Parasitol., 206(1-2): 48-54.

25. Lal, RB., Dhawan, RR., Ramzy, RM., Farris, RM. and Gad, AA. (1991) C-reactive protein in patients with lymphatic filariasis: Increased expression on lymphocytes in chronic lymphatic obstruction. J. Clin. Immunol., 11(1): 46-53. 